ISSN: 2224-0616

Int. J. Agril. Res. Innov. \& Tech. 6 (1): 21-25, J une, 2016

Available online at http:// www.ijarit.webs.com

\title{
EVALUATION OF POTATO (Solanum tuberosum L.) GENOTYPES FOR RESISTANCE TO LATE BLIGHT AT SINANA SOUTHEASTERN ETHIOPIA
}

\author{
Getachew Asefa ${ }^{*}$, Wassu Mohammed ${ }^{2}$ and Tesfaye Abebe ${ }^{3}$ \\ Received 10 February 2016, Revised 27 May 2016, Accepted 21 June 2016, Published online 30 June 2016
}

\begin{abstract}
Late blight caused by Phytophthora infestans (Mont.) de Bary, is one of the most significant constraints to potato production in Bale high lands and other regions of Ethiopia. Hence, this requires to develop high yielding and late blight resistant varieties. Therefore, this study was conducted to determine host resistance of potato against Phytophthora infestans in order to develop late blight resistant/tolerant genotypes. The experiment was laid out in randomized complete block design with three replications at Sinana Agricultural Research Center during 2014 main cropping season. The genotypes showed highly significant $(\mathrm{P} \leq 0.01)$ differences for all the characters studied. Genotypes exhibited wide ranges of mean values for all characters. The highest total tuber yield (46.1 t ha-1) was obtained from the advanced clone, CIP-392640.524 followed by Belete (41 t ha-1). Late blight appeared early on farmer's cultivar Kellacho (48 days after planting) and late on advanced clones CIP399062.102(74 days after planting). Percent severity index (PSI) and area under disease progress curve (AUDPC) ranged from 33.91 to $91.67 \%$ and 105 to 2370, respectively. Eleven newly introduced clones and the released variety "Belete" recorded PSI 33 to $39.7 \%$ and AUDPC 105 to 264.1. Hence, these genotypes can be categorized as moderately resistant. The study revealed the presence of considerable variability in tested genotypes for economically important traits and the higher chance of selecting genotypes with high yield and moderately resistant to late blight. However, it appears that further evaluation of genotypes across seasons and locations to identify genotypes that could be released as varieties seem to be quite pertinent.
\end{abstract}

Keywords: Disease Progress Curve; Genotype; Late Blight; Percent Severity Index

${ }^{1}$ Oromia Agricultural Research Institute, Sinana Agricultural Research Center; PO. Box. 208; Bale-Robe, Ethiopia.

${ }^{2}$ Haramaya University, School of Plant Science, P.O.BOX 138, Dire Dawa, Ethiopia.

${ }^{3}$ Amhara Agricultural Research Institute, Adet Agricultural Research Center, P.O. Box 08, Bahir Dar, Ethiopia.

*Corresponding author's email: getachewas@yahoo.com (Getachew Asefa)

\section{Introduction}

Potato late blight, caused by the Phytophthora infestans (Mont.) de Bary, is one of the primary problems faced by small-scale potato producers in high lands of Ethiopia. Late blight can destroy a potato field within a few days (Razukas and Jundulas, 2005). If not controlled, losses may reach $100 \%$ (Rubio-Covarrubias et al., 2005) and even lower infection levels may make the crop unfit for storage (Heinfnings, 1987). In the highlands of Ethiopia, late blight and bacterial wilt (Ralstonia solanacearum) are the most important economic diseases that cause an estimated yield loss of up to $70 \%$ (Shiferaw et al., 2009). Late blight is especially important in the traditional potato growing areas.

The search for genetic resistance to late blight has intensified, since it is a practical and economic way of controlling the disease. Initially, the search concentrated on specific resistance (Forbes and Landeo, 2006). The resistant variety development, which involves evaluation, selection, release and registration procedures pass through several stages. Some countries such as Ethiopia, the potato breeding programs depend entirely on CIP materials. In the absence of creating variation through crossing in the country, it is necessary to introduce potato genotypes every time from the source. The introduced genotypes need to be evaluated for target areas or for wide adaptability across regions in the country. Accordingly, this study was conducted to determine host resistance of potato against Phytophthora infestans and to develop late blight resistant/ tolerant genotypes.

\section{Materials and Methods}

\section{Experimental site}

The experiment was conducted in Southeastern Ethiopia, Bale Zone, at Sinana Agricultural Research Center during 2014 main cropping season. Sinana is located at $070 \mathrm{~N}$ and $40^{\circ} 10^{\prime} \mathrm{E}$ at an altitude of 2400 (m.a.s.l). The area possesses a bimodal rainfall type. This bimodal rainfall system has created conducive opportunities to 
produce crops twice annually or double production in a season. Average annual maximum and minimum temperatures are 21 and $9^{\circ} \mathrm{C}$, respectively. The dominant soil type is pellic vertisol and slightly acidic (Nefo et al., 2008).

\section{Experimental materials and design}

A total of 24 potato genotypes which consists of 20 advanced clones, three released varieties as standard checks and one farmers' cultivar in Bale were planted during the main cropping season of 2014. The farmers' cultivar Kellacho that is susceptible to late blight was used as local check. Belete is known as resistant variety to late blight while Ararsa and Guddane are moderately resistant varieties.

The experiment was arranged in randomized complete block design (RCBD) with three replications. The spacing between rows and plants was $0.75 \mathrm{~m}$ and $0.30 \mathrm{~m}$, respectively. The spacing between plots and adjacent replications was $1 \mathrm{~m}$ and $1.5 \mathrm{~m}$, respectively. At both end of each row, tubers of known late blight susceptible
(Kellecho) was planted and were used as inoculum sources or "spreader rows". Thus, each genotype or plant in each plot had a chance to receive ample amount of inoculum sources under natural inoculum distribution. The middle rows were used for data collection.

\section{Data collection}

Days to late blight appearance (DLA) was recorded by counting days from planting to the first appearance of late blight symptoms in each plot (genotype).

Disease severity was taken on the basis of the percentage of leaf area affected by late blight. The reading was started on the onset of late blight (1$5 \%$ infection). After onset of the disease scoring was continued at an interval of seven days until nearly 74 days after planting. The 1-9 disease score scale described by Heinfnings (1987) was used.

Percent severity index (PSI) was calculated from disease severity.

$$
\text { Percent Severity index } \%=\frac{\text { Summation of numerical rating }}{\text { No.plants examined } \times \text { Maximum disease score }} \times 100
$$

The calculated percent severity index was used to classify genotypes in to highly resistant (up to 5), resistant (5-20), moderately resistant (21-40) and susceptible (>40) (Mohan and Thind, 1999).

Area under disease progress curve: was calculated according to Campbell and Madden (1990) formula and it was interpreted directly without transformation as the higher the AUDPC, the more susceptible genotype (CIP, 2006).

$\mathrm{AUDPC}=\sum_{i=1}^{n-1}\left(\frac{y i+y i+1}{2}\right)\left(t_{i+1}-t_{i}\right)$

Where " $\mathrm{t}$ " is the time of each reading, " $\mathrm{y}$ " is the percent of affected foliage at each reading and " $n$ " is the number of readings. The variable " $\mathrm{t}$ " can represent Julian days, days after planting.

\section{Data analysis}

Collected data was subjected to analysis of variance (ANOVA) for RCBD following the procedure outlined by Gomez and Gomez (1984) using SAS ver. 9.1.3 computer software. Means that are significantly different were compared using Duncan Multiple Range Test (DMRT) of probability at $1 \%$ and $5 \%$ probability of significance.

\section{Results and Discussion}

\section{Analysis of Variance}

Analysis of variance indicated the presence of highly significant $(\mathrm{P} \leq 0.01)$ differences among genotype for all traits. This may allow breeders to select resistant genotypes to enhance the productivity of the crop. This is in line with J aime et al. (2014) who indicated significant different among 10 potato cultivars under studies.

\section{Mean performance of genoty pes}

Potato genotypes had a wide range of variations. Total tuber yield ranged from 0.8 to $46.1 \mathrm{t} \mathrm{ha}^{-1}$ with mean performance of $19.4 \mathrm{t} \mathrm{ha}^{-1}$ (Table 1). Mean total tuber yield of released varieties (Belete, Gudanie and Ararsa) was within the range of 15.9 to $41 \mathrm{t} \mathrm{ha}^{-1}$. The four advanced clones gave total tuber yield higher than the mean tuber yield of the two released varieties (Gudanie and Ararsa) while one clone (CIP-392640.524) had statistically the same mean total tuber yield with the best performing released variety Belete. Addisu et al. (2013) and Baye (2002) also reported some of the newly introduced potato genotypes had higher tuber yield than the existing commercial potato varieties. This indicated the presence of variation in genotypes under study for total tuber yield that can be exploited in improving the crop.

Late blight appeared early at 48 days after planting on farmers cultivar Kellacho and other five advanced clones (CIP-399053.15, CIP397079.26, CIP-396039.103, CIP-391930.1 and CIP-391381.9) followed by three advanced clones 
(CIP-399078.11, CIP-396031.201 and CIP393382.44) which appeared at 53 days after planting. Late blight appeared very late on CIP399062.102 at 74 days after planting. The disease appeared at 70 days on Belete and at 63 days on Ararsa and Guddanie. There was wide range difference of 26 days between the first disease symptom appearance on susceptible and relatively resistant genotypes. J aime et al. (2014) also reported that potato genotypes which developed late blight symptom early are susceptible and genotypes that developed late blight in the crop cycle are resistant.

The calculated percent severity index ranged from 33.00 for CIP-391058.175, CIP-395096.2, CIP395114.5, CIP-396031.201 and Belete to $91.67 \%$ for advanced clone (CIP-391930.1). From all 24 genotypes, there was no genotype with percent severity index of $<20$ at nearly 80 days after planting. Hence, there were no highly resistant and resistant genotypes from the newly introduced materials and released varieties. However, eleven advanced clones and Belete had percent severity index that ranged from 33.00 to 39.70 and can be categorized as moderately resistance while others including released varieties Guddine and Ararsa recorded above $40 \%$ and categorized as susceptible.

The calculated AUDPC ranged from as low as 105 for CIP-391058.175, CIP-399062.102, CIP395096.2, Bellete and as high as 2370 for CIP397079.26. Most of the genotypes including the released variety Ararsa and Gudenie had high AUDPC. According to Campbell and Madden (1990), from 24 potato genotypes- CIP-395096.2, CIP-395077.12, CIP-99062.102, Belete, CIP395114.5, CIP395017.242, CIP-396240.23, CIP391058.175, CIP396029.205, CIP396031.201, CIP-3920524 and CIP-396244.12 categorized as tolerant. However, other genotypes including released varieties Ararsa and Gudaine were considered as susceptible. The AUDPC is very convenient summary of plant disease epidemics that incorporates initial intensity, the rate parameter and duration of epidemic, which determine final disease intensity (Andre et al., 2014). Hence, the effect of disease resistance on crop can be evaluated by using area under disease progress curve (Boiteux et al., 1995). This is in agreement with the finding of J aime et al. (2014) who reported that high susceptible cultivar Shepody had the highest AUDPC value among 10 potato cultivars in Argentina.

Table 1. Mean performance of 24 potato genotypes for yield and late blight disease parameters at Sinana in 2014 bona cropping season

\begin{tabular}{|c|c|c|c|c|c|c|}
\hline Genotypes & MTY & unMTY & TTY & DLA & PSI(\%) & AUDPC \\
\hline CIP-395096.2 & $0.06^{n}$ & $0.7 \mathrm{~h}-\mathrm{j}$ & $0.8^{\mathrm{j}}$ & $63^{b-d}$ & $33.0^{\mathrm{a}}$ & $105^{\mathrm{a}}$ \\
\hline CIP-391381.9 & $3^{1-n}$ & $3.2^{b}$ & $6^{h-j}$ & $48 e^{e}$ & $80.3^{\mathrm{c}-\mathrm{e}}$ & 1753 e \\
\hline CIP-395077.12 & $11.3^{h-1}$ & $0.7^{\mathrm{h}-\mathrm{j}}$ & $12^{g-i}$ & $63^{b-d}$ & $39.7^{\mathrm{a}}$ & $248.6^{a}$ \\
\hline СIP-399062.102 & $23.2^{\mathrm{d}-\mathrm{f}}$ & $1.3^{\mathrm{f}-\mathrm{i}}$ & $24.5^{\mathrm{c}-\mathrm{f}}$ & $74.67 a$ & $38.67^{a}$ & $105^{\mathrm{a}}$ \\
\hline Belete & $39.4^{\mathrm{ab}}$ & $0.7 \mathrm{~h}-\mathrm{j}$ & $41 \mathrm{ab}$ & $70^{\mathrm{ab}}$ & $33^{a}$ & $105^{a}$ \\
\hline СIP-396039.103 & $21^{e-g}$ & $1.3^{\mathrm{f}-\mathrm{i}}$ & $23.5^{c-f}$ & $48^{\mathrm{e}}$ & $68^{\mathrm{b}-\mathrm{e}}$ & 1119. ${ }^{d}$ \\
\hline CIP-399078.11 & $15.2^{f-i}$ & $0.7^{\mathrm{h}-\mathrm{j}}$ & $15.9^{\mathrm{f}-\mathrm{h}}$ & 53 de & $67^{b-e}$ & $575.2^{\mathrm{ab}}$ \\
\hline CIP-395112.19 & $13.2^{\mathrm{g}-\mathrm{k}}$ & $0.3^{\mathrm{j}}$ & $13.6^{\mathrm{eh}}$ & 72.3 $3^{\mathrm{ab}}$ & $55.3^{a-c}$ & $332.3 \mathrm{ab}$ \\
\hline CIP395017.242 & $21.5^{\mathrm{eg}}$ & $1.4 \mathrm{e}^{\mathrm{i}}$ & $22.9 \mathrm{c}-\mathrm{f}$ & 72.3ab & 38.67 a & $145.8^{a}$ \\
\hline Kellacho & $1.4 \mathrm{mn}$ & $1.3^{f-i}$ & $2.7^{\mathrm{ij}}$ & $48^{e}$ & 82.0 de & 2014. $1^{\text {ef }}$ \\
\hline CIP-395114.5 & $32.7 \mathrm{bc}$ & $0.6^{h-j}$ & 33.6 bc & $62.6^{b-d}$ & 33.0a & $122.5^{\mathrm{a}}$ \\
\hline CIP-396240.23 & $25.5^{\mathrm{c}-\mathrm{e}}$ & $1.5^{e-i}$ & $26.8 \mathrm{c}-\mathrm{e}$ & $62.6^{\mathrm{b}-\mathrm{d}}$ & $36.67 \mathrm{a}$ & $180.8^{a}$ \\
\hline CIP-397079.26 & $4.1^{\mathrm{k}-\mathrm{n}}$ & $0.2^{\mathrm{j}}$ & $4^{\mathrm{ij}}$ & $48 .^{e}$ & $91.33^{e}$ & $2370^{g}$ \\
\hline CIP391058.175 & 29 c-e & $1.5^{\mathrm{e} h}$ & $31^{\mathrm{bc}}$ & $65.3^{a-c}$ & $33^{a}$ & $105^{a}$ \\
\hline CIP396029.205 & $26^{c-e}$ & $0.7^{\mathrm{h}-\mathrm{j}}$ & $27 \mathrm{~cd}$ & $63 \mathrm{~b}-\mathrm{d}$ & $37.0^{\mathrm{a}}$ & $189.1^{\mathrm{a}}$ \\
\hline Ararsa & $13 g-j$ & $1.1^{g-j}$ & $14^{\mathrm{eh}}$ & $63^{b-d}$ & 57..$^{\mathrm{a}-\mathrm{d}}$ & $372.1^{a b}$ \\
\hline CIP-399053.15 & $7.5^{\mathrm{i}-\mathrm{n}}$ & $2.2^{\mathrm{c}-\mathrm{f}}$ & $9 g-j$ & $48 e^{e}$ & $66^{b-d}$ & $1191.6^{\mathrm{d}}$ \\
\hline CIP-393382.44 & $10^{\mathrm{i}-\mathrm{m}}$ & $0.6^{\mathrm{h}-\mathrm{j}}$ & $11^{g-j}$ & 53 de & $65.6^{b-d}$ & $1134.5^{\mathrm{d}}$ \\
\hline CIP396031.201 & $5.5^{\mathrm{j}-\mathrm{n}}$ & $1 \mathrm{~h}-\mathrm{j}$ & $6.6^{h-j}$ & $53^{\mathrm{de}}$ & 33.33a & $161.2^{\mathrm{a}}$ \\
\hline CIP395017.229 & $14^{f-j}$ & $2.9 \mathrm{~b}-\mathrm{d}$ & $16^{\mathrm{d}-\mathrm{h}}$ & $58 \mathrm{c}-\mathrm{e}$ & $56.67 \mathrm{ad}$ & $750.5^{\mathrm{c}}$ \\
\hline Guddane & 20 eh & $2.3 \mathrm{c}-\mathrm{e}$ & $23 \mathrm{c}-\mathrm{f}$ & $63 b-d$ & 43.3ab & $581.0^{\mathrm{bc}}$ \\
\hline CIP-3920 -524 & $43.7^{\mathrm{a}}$ & $2.4^{\mathrm{c}-\mathrm{e}}$ & $46.1^{\mathrm{a}}$ & $58^{c-e}$ & $36.67^{a}$ & $186.7^{\mathrm{a}}$ \\
\hline CIP-391930.1 & $3.3^{\mathrm{i}-\mathrm{n}}$ & $8.7 \mathrm{a}$ & $11 g-i$ & $48 \mathrm{e}$ & $91.67 \mathrm{e}$ & $2165.6^{\mathrm{fg}}$ \\
\hline CIP-396244.12 & $31^{\mathrm{b}-\mathrm{d}}$ & $1.4^{\mathrm{f}-\mathrm{i}}$ & 33 bc & $65.3^{a-c}$ & $37.00^{a}$ & $264.1^{\mathrm{a}}$ \\
\hline Range & $0.06-43$ & $0.65-8.7$ & $0.76-46$ & $48-74.67$ & 33-91.67 & $105-2370$ \\
\hline Mean & 17.5 & 1.721 & 19.41 & 59.31 & 53.7 & 680 \\
\hline CV\% & 28.2 & 29.2 & 29.3 & 10.3 & 24.9 & 24.6 \\
\hline Level of significance & ** & $* *$ & $* *$ & $* *$ & $* *$ & $* *$ \\
\hline
\end{tabular}

Means followed by the same letter within a column are not significantly different at the prescribed level of probability. $* *=$ significant and ns $=$ non-significant (at $1 \%$ and $5 \%$ ). MTY marketable tuber yield, unMTY $=$ unmarketable tuber yield, TTY $=$ total tuber yield $t$ ha-1, DLA = days to late blight appearance, PSI = percent severity index, AUDPC $=$ area under disease progress curve, $\mathrm{CV}=$ coefficient of variation 
In 2014 main cropping season, there was high severity of late blight on potato in Bale high lands (personal observation). At 48 days after planting, late blight appeared on some genotypes. This indicated that in the process of improving potato variety through selection attention should be given to assess the disease onset as early as possible. Similar results were reported by Sharma et al. (2013), which indicated late blight severity observations in the field should be started at 30 days after planting and continued up to 76 days until the susceptible check had 100\% infection.

Considering both disease parameters, (PSI and AUDPC) 11 newly introduced genotype and one released variety Belete were categorized as moderately resistant. Thus, these genotypes are found promising for further improvement as breeding materials. Others may be considered for cultivation using other late blight management options especially in the case of Ararsa and Gudaine. Similar results were reported by Shiferaw et al. (2009) that moderately resistant cultivar, Gudanie, had a clear AUDPC response to additional fungicide sprays, although apparently for about three sprays. Several research on potato late blight have demonstrated that highly resistant (immune or nearly immune) phenotypes can frequently indicate an active major $\mathrm{R}$ gene, for which compatibility in the pathogen population is absent or extremely rare.

If an incompatible potato genotype is released for use by farmers in most cases there will be selection of compatible pathogen population and a corresponding "loss" of resistance (Forbes, 2012). For this reason, some researchers have recommended selection of those phenotypes, which demonstrate resistance, but are still infected (Forbes and Landeo, 2006).

\section{Conclusions}

In conclusion, the present study revealed the existence of variability for tuber yield and resistance to late blight. This suggested the higher chance of selecting genotypes with moderate resistance/ tolerance to improve the productivity of the crop. In addition, the future potato improvement program in the study area should include genotypes highly resistant to late blight. The identified promising genotypes in this study showed only moderate resistance to late blight which can be surpassed by the disease, as the pathogen is known with high mutable characteristics that make resistant varieties susceptible soon after they are deployed.

\section{Acknowledgments}

The Authors would like to thank all Horticulture and Seed Spice case team staff of Sinana Agricultural Research Center. The Financial support provided by Oromia Agricultural Research Institute is also dully acknowledged.

\section{References}

Addisu, F., Yohannes, P. and Habtamu, Z. 2013. Genetic variability and association between agronomic characters in some potato (Solanum tuberosum L.) genotypes in SNNPRS Ethiopia. Int. J. Biodiv. Conserv. 5(8): 523-528.

André, D., Peter, K. and Oscar, O. 2014. Potatoes for sustainable global food security. Potato Res. 57: 185-199. doi: 10.1007/s11540-0149265-1.

Baye, B. 2002. Variability and Association of tuber yield and related trait in potato (Solanum tuberosum L.). MSc. Thesis. Haramaya University, Haramaya. 41p.

Boiteux, L.S., Reifschneider, F.J.B., Fonseca, M.E.N. and Buso, J.A. 1995. Search for sources of early blight (Alternaria solani) field resistance not associated with vegetative late maturity in tetraploid potato germplasm. Euphytica 83(1): 63-70.

Campbell, C.L. and Madden, L.V. 1990. Introduction to Plant Disease Epidemiology. New York: John Wiley and Sons. pp. 235-238.

CIP (International Potato Center). 2006. Procedures for standard evaluation trials of advanced potato clones. An International Cooperators' Guide. pp. 41-53.

Forbes, G.A. 2012. Using host resistance to manage potato late blight with particular reference to developing countries. Potato Res. 55: 205-216.

Forbes, G.A. and Landeo, J.A. 2006. Late Blight In: J. Gopal and P. KSM (Eds.), Handbook of Potato Production, Improvement, and Postharvest Management Binghamton, NY: Haworth Press Inc. pp. 279-314.

Gomez, K.A. and Gomez, A.A. 1984. Statistical procedures for agricultural research $\left(2^{\text {nd }}\right.$ ed.). J ohn Wiley and Sons, NewYork, 680p.

Heinfnings, J.W. 1987. Late blight of potato (Phytophthora infestans), Technical information Bulletin 4. Lima. Peru. 25p.

Jaime, S., Ivette, A., Florence, E. and Philippe, B. 2014. Resistance to Phytophthora infestans in Solanum tuberosum landraces in Southern Chile. Trop. Plant Path. 39(4): 307-315.

Mohan C. and Thind T.S. 1999. Mohan, C., and Thind, T.S., 1999. Resistance and relative performance of some new fungicides for active management of potato late blight in Punjab. Indian J. Mycol. Plant Path. 29(1): 23-37.

Nefo, K., Geleto, T. and Aman A. (ed.) 2008. Fifteen years achievement: Oromia Agricultural Research Institute, Sinana Agricultural Research Center, Bale-Robe, Southeast Ethiopia. 37p. 
Razukas, A. and Jundulas, J. 2005. Potatoes breeding in Lithuania. Lithuanian Inst. Hort. 24(3): 187-195.

Rubio-Covarrubias, O.A., Douches, D.S., Hammershmidt, R., daRocha, A. and Kirk, W.W. 2005. Effect of temperature and photoperiod on symptoms associated with resistance to Phytophthora infestans after leaf penetration in susceptible and resistant potato cultivars. America J. Potato Res. 82: 139-146.

Sharma, B.P., Forbes, G.A., Manandhar, H.K. Shrestha, S.M. and Thapa, R.B. 2013
Determination of resistance to Phytophthora infestans on potato plants in field, laboratory and greenhouse conditions. J. Agril. Sci. 5(5): 148-157. doi: 10.5539/jas.v5n5p148.

Shiferaw, M., Tameru, A. Bekele, K. and Forbes, G. 2009. Evaluation of contact fungicide spray regimes for control of late blight (Phytophthora infestans) in southern Ethiopia using potato cultivars with different levels of host resistance. Trop. Plant Path. 36(1): 21-27. 